\title{
Growth and Yield of 15-Year Plantations of Pine, Spruce and Birch in Agricultural Land
}

\author{
*Mudrite Daugaviete, Andis Lazdins, Dagnija Lazdina, Kristaps Makovskis, Uldis Daugavietis \\ Latvian State Forest Research institute "Silava", Rīgas street 111, Salaspils, LV-2169, Latvia
}

\begin{abstract}
The growth data and the potential returns from 15-year-old plantations of pine Pinus sylvestris L. (6 trial sites), spruce Picea abies Karst L. (9 trial sites) and silver birch Betula pendula Roth (13 trial sites), established in abandoned agricultural lands in a variety of soil types (sod calcareous, anthrosols, podzolic, podzols, gley, podzolic gley, alluvial), using the planting density 2,500 and 3,300 and also 5,000 trees/ha are analysed.

For tree plantations in agricultural soils (alluvial sod-gley, gley-sod podzolic, sod-podzolic gley, typic podzol) at the survival of $80-98 \%$ the stock volume for 15 -year pine is as high as $102-155 \mathrm{~m}^{3} \mathrm{ha}^{-1}$ with the volume growth 5.72-8.94 $\mathrm{m}^{3} \mathrm{ha}^{-1}$ per year; the same indices for spruce in agricultural soils (gley sod-calcareous, sodpodzolic, cultivated, sod-podzolic gley, alluvial sod-gley, base-unsaturated brown) are 75-98 $\mathrm{m}^{3} \mathrm{ha}^{-1}$ and 10.26$15.76 \mathrm{~m}^{3} \mathrm{ha}^{-1}$, respectively. For 15 -year plantation birch the mentioned indices may vary from 61 to $169 \mathrm{~m}^{3} \mathrm{ha}^{-1}$ and from 7.54 to $29.82 \mathrm{~m}^{3} \mathrm{ha}^{-1}$ per year. The lowest volume growth (4.66 $\mathrm{m}^{3}$ ha-1 per year) is for birch in heavy clay soil (gleyic sod-podzolic), the highest (29.72-29.82 $\mathrm{m}^{3} \mathrm{ha}^{-1}$ per year) - in cultivated soils and pseudogley soil.

Plantation cultivation of pine, spruce and birch in agricultural lands may by the age of 15 years yield with a profit such forest products as pulpwood, fire wood and woody biomass. The gross income gained from first commercial thinnings of plantation pine, utilizing pulpwood, fire wood and logging residue biomass, may vary from 679-2267 EUR ha' ${ }^{-1}$, for spruce the same indices are 1644-3272 EUR ha-1, for birch - 683-2188 EUR ha-1. Key words: pine; spruce; birch; growth and yield; stock volume; biomass; gross income.
\end{abstract}

\section{Introduction}

The plantations of ligneous plants and forest stands have been at the center of attention both in economic, ecological, and social sectors for several centuries now (West, 2014). Scientists and practitioners are unanimous: as the population of the world increases, so does the need for timber, wood biomass and its products, and forest plantation industry plays invaluable role in satisfying these needs. The worldwide experience shows that the plantations of ligneous plants are the main source of timber and wood biomass for providing building materials, manufacturing of paper, and energy wood production. Besides, these plantations serve as carbon sinks and give substantial contribution in reducing the greenhouse effect (Carnus et al., 2006; Del Lungo, Ball \& Carll, 2006; Zanchi et al., 2007; Paquette \&
Messier, 2010; West, 2014; Global Forest Resources Assessment, 2015).

In the boreal and semi-boreal forest zone, as well as in the countries of the northern part of Europe - Norway, Finland, Sweden, the Baltic states - the main coniferous tree species planted in the forest plantations are those of the pine (Pinaceae) family - pines (Pinus spp.- Pinus sylvestris, Pinus murayana, Pinus contorta a.o.), spruce (Picea spp.Picea abies, Picea sithensis a.o.), larches (Larix spp.Larix decidua, Larix sibirica, Larix x eurolepis a.o.), as the main deciduous tree species we can mention birch family (Betulaceae) species: birches ((Betula pendula, B.pubescens), alders (Alnus glutinosa, Alnus incana a.o.), hybrid aspens, poplars (Populus tremula $x$ P.tremuloides, Populus $x$ canadensis a.o.), osier varieties (Salix spp.) a.o. (Global

\footnotetext{
* Corresponding Author's email: mudrite.daugaviete@silava.lv
} 
Forest Resources Assessment, 2015, Nabuur et al., 2014).

Scientists conclude that when selecting areas for plantation establishment not only the choices of the location - soil type, hydrological regime and microclimate must be taken into consideration, but also, depending on those characteristics, the plantation establishment technology, one or several tree species, management regime, and potential future products must be determined. Depending on the type of the plantation (short-rotation - for obtaining biomass, pulpwood, veneer log, sawlog production) appropriate tree species must be selected and establishment density (500-5000 trees/ha or 10 000-25 000, species of ligneous plants - Salix species, willow species, viburnums, elders (Mather, 1993; Johansson, 1996; Savill et al., 1997; Brown, 2000; Weber, 2000; Daugaviete et al., 2003; Feedman, 2005; Zanchi et al., 2007; Halldorsson, Oddsdottir \& Eggertsson, 2007; Hynynen et al., 2010; Lazdin̄š, 2011; Lazdins et al., 2011; Liepiṇš, 2011; West, 2014; Daugaviete et al., 2015).

Expierence with afforestation demonstrates that throughout Nordic region of the EU, there has been increased emphasis on the use of native species pine, spruce and birch (Savill et al., 1997; Sedjo \& Botkin, 1997; Weber, 2000; Halldorsson, Oddsdottir \& Eggertsson, 2007; Zanchii et al., 2007; Hynynen et al., 2010; Kund et al., 2010; Tullus et al., 2012; West, 2014). The scientists and practitioners came to the conclusion - in Northen Europe, birch and spruce are comerrcially the most important tree species for plantation forestry (Johansson, 1996; Savill et al., 1997; Rytter \& Werner, 2007; Haldorsson, Oddsdottir \& Eggertsson, 2007; Hynynen et al., 2010; West, 2014).

The issue about rational land utilization became topical once more in the mid-90s of the 20th century when, following the agrarian reform, $36.6 \%$ of agricultural lands (AL) and $42 \%$ of forest land ended up in the possession of private owners ${ }^{1}$.

From 1999-2015 the area of AL afforested with improved planting material already constituted 32357 ha, including 9502 ha of plantation forests $(29.4 \% \text { of afforested areas })^{2}$.

In Latvia, substantial research about the growth and management of pine, spruce, birch, aspen, hybrid aspen, ash, larch stands in AL was done by forest scientists P.Sarma (1949), P.Maike (1953), R.Sacenieks and V.Gaross (1961).

In the 1960s the growth of birch plantations on former AL was studied by P.Maike, who concluded that the plantations in these areas reach the site index of I - Ia and that in 1950s their standing volume has been up to $439 \mathrm{~m}^{3} \mathrm{ha}^{-1}$. Tree trunk form and pruning evaluated as being good, and these plantations have been deemed suitable for obtaining good quality industrial timber (Maike, 1952).

Extensive research on pine and spruce growth on former AL between 50s and 70s of the 20th century has been done by Sarma (1949), Sacenieks, Gaross (1961), a.o. Scientists have concluded that artificially established and natural stands on former AL develop much faster in comparison with natural stands in forest soils. For spruce, the current annual height increment culminates in the age class I, but the standing volume - in the age class II. Plantations on former AL show high site index class: spruce plantations Ia-Ic, pine plantations - Ia site index. Spruce stand mean annual increment reaches 10-12 $\mathrm{m}^{3} \mathrm{ha}^{-1}$ per year (Sarma, 1949). 48-year-old spruce pure stand reaches 361$548 \mathrm{~m}^{3} \mathrm{ha}^{-1}$, whereas pine pure stand reaches 291-298 $\mathrm{m}^{3} \mathrm{ha}^{-1}$ at the age of 35-40 years.

Since 1995 research has been done on the growth of plantation forests on former AL, assessing the growth of various tree species and stem quality in current and former year plantations (Daugaviete et al., 2003; Daugaviete, 2005; Daugaviete, K.Liepiņš \& J.Liepiņš, 2011; Daugaviete et al., 2015, Lazdiņš, 2011, Liepiňš, 2011). It has been concluded in this research that in age class I (0-20 years) stands on former $\mathrm{AL}$ show higher growth indices (mean height, mean diameter, volume current annual increment), but in the following age classes the growth evens out.

The research continues, as the processes in the environment and the plantation establishment technologies have changed significantly. In the last decade in Latvia, due to both climatic changes and rational land management guidelines, introduction of regulations on growing plantation forests, shortrotation plantations and plantations of ligneous plants that allow for the possibility of establishing ligneous plant plantations on agricultural lands - plantations the maximum growth period of which is up to 15 years, without transforming the land into forest land ${ }^{3}$, improvement of the volume and quality of the grown planting material, scientists are carrying out in-depth research about the development and productivity of plantations and plantation forests on afforested AL, as well as the assessment of these stands.

The aim of the research: to explain the growth and productivity of 15-year-old plantation-type stands of most widespread tree species - pine, spruce,

$1 \mathrm{http} / / /$ www.csb.gov.lv/statistikas-temas/metodoloǵija/lauksaimnieciba-izmantojamas-zemes-izmantošana-38278.htm

2 http://www.vmd.gov.lv/StateForestService.LatvianForest Sector, 2015

3 http://likumi.lv/doc.php?id=87480 


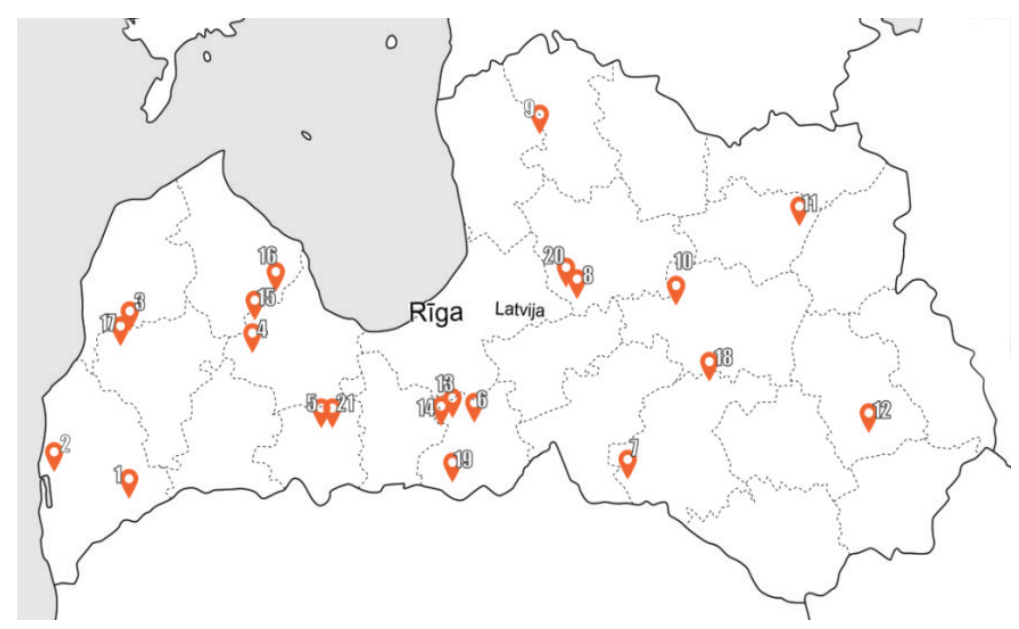

Figure 1. Site location of experimental plots.

birch - in various AL soils, and assess the economic effectiveness of these plantations.

\section{Materials and Methods}

The research material has been gathered at 21 established experimental plantations and 150 sample plots in afforestations of AL in the territories of Grobina, Priekule, Kandava, Dobele, Ozolnieki, Bauska, Viesite, Amata, Koceni, Madona, Gulbene and Rezekne municipalities (Table 1; Figure 1).

Legend: Birch (Betula pendula Roth.), Scots pine (Pinus sylvestris L.), Norway spruce (Picea abies (L.) Karst.).

In each plantation, the tree growth and productivity monitoring has been conducted, determining the following parameters: tree height, $\mathrm{m}$; tree diameter at breast height, $\mathrm{cm}$; tree stem quality knottiness below $2 \mathrm{~m}$, above $2 \mathrm{~m}$, spike knot - below $2 \mathrm{~m}$ and above 2 $\mathrm{m}$, stem, $\mathrm{m}$. Measurements repeated every 1-5 years. The first 5 years after establishment of plantations measurements repeated each year. Total monitoring period was 15 years.

In each sample plot standing volume has been calculated (Liepa, 1996), volume of mean tree, standing volume current annual increment, biomass of each tree components (stem, branches, leaves), and freshly cut biomass was calculated per unit area.

The mean diameter of young stands, the average height of which exceed $9 \mathrm{~m}$, had been calculated by the results of tree diameter measurement - as the basal area weighted mean diameter of diameter classes.

Individual tree stem volume has been calculated with the formula (Liepa, 1996):

$$
v=\psi L^{\alpha} D^{\beta \lg L+\varphi}
$$

where:

$v$ - stem volume with bark, $\mathrm{m}^{3}$;
$L$ - stem length, m;

$D$ - stem breast height diameter with bark, $\mathrm{cm}$;

$\psi, \alpha, \beta, \varphi-$ the coefficients dependent on tree species (Liepa 1996).

Using the sample tree data, the stand volume current annual increment has been calculated with the formula (Liepa 1996):

$$
Z_{M}=k G\left[\frac{2 Z_{D}\left(H-2 Z_{H}+4\right)}{10 D+Z_{D}}+Z_{H}\right]
$$

where:

$Z_{M}-$ current actual stand volume increment, $\mathrm{m}^{3} / \mathrm{ha}$;

$H$ - average stand height, $\mathrm{m}$;

$G$ - stand basal area, $\mathrm{m}^{2} / \mathrm{ha}$;

$k$ - empirical ratio

$D$ - mean breast height diameter of the stand, cm;

$Z_{D}$ - current increment of DBH of the stand, $\mathrm{mm}$; $Z_{H}$ - current increment of the stand height, $\mathrm{m}$.

To determine the volume of the above-ground biomass produced by various tree species, three sample trees were cut down in each plantation at root collar - one Kraft class I and two Kraft class II. After felling the tree height has been measured using tapemeasure (with a precision to $1 \mathrm{~cm}$ ), the stem pruned and cut into meter long sections. The sample tree weight determined on site by weighing separately: stem wood, dry branches, live branches.

Wood samples of each tree were collected for drying in laboratory - dry branch, 3 live branches (from different sections of the crown) and three disks (from various sections of the stem).

To carry out the stem analysis, wood disks have been acquired from each tree - in the middle of $0 \mathrm{~m}$, $1.3 \mathrm{~m}$, and meter long sections $(0.5 ; 1.5 ; 2.5$ etc.). On the bottom of each disk the tree number, cut height and northerly direction has been noted. Wood disks have been analyzed with the computer software 
Characteristics of experimental plots

Table 1

\begin{tabular}{|c|c|c|c|c|c|}
\hline $\begin{array}{l}\text { Site location/ } \\
\text { district/ } \\
\text { farm }\end{array}$ & Latitude N & Longitude E & $\begin{array}{c}\text { Soil type } \\
\text { (Karklins 2008) }\end{array}$ & Tree species & $\begin{array}{c}\text { Number of trees } \\
\text { ha }^{-1}\end{array}$ \\
\hline $\begin{array}{c}\text { Grobina/ } \\
\text { Bērzpurvi } \\
\text { (Grob/ } \\
\text { Bērz) }\end{array}$ & $56^{\circ} 23^{\prime} 29^{\prime \prime}$ & $21^{\circ} 07^{\prime} 11^{\prime \prime}$ & $\begin{array}{c}\text { TP } \\
\text { Typical podzol }\end{array}$ & $\begin{array}{l}\text { Birch, } \\
\text { Pine }\end{array}$ & $\begin{array}{l}3300 \\
5000\end{array}$ \\
\hline $\begin{array}{l}\text { Kandava/ } \\
\text { Aizlolas } \\
\text { (Kand/ } \\
\text { Aizl) }\end{array}$ & $56^{\circ} 55^{\prime} 11^{\prime \prime}$ & $22^{\circ} 41^{\prime} 30^{\prime \prime}$ & $\begin{array}{c}\text { /GSC } \\
\text { Gley-sod } \\
\text { calcareous soil }\end{array}$ & $\begin{array}{c}\text { Birch, } \\
\text { Scots pine } \\
\text { Norway spruce }\end{array}$ & $\begin{array}{l}3300 \\
5000 \\
2000\end{array}$ \\
\hline $\begin{array}{l}\text { Kuldiga/ } \\
\text { Rūmnieki } \\
\text { (Kuld/ } \\
\text { Rūmn) }\end{array}$ & $57^{\circ} 03^{\prime} 3^{\prime \prime}$ & $21^{\circ} 46^{\prime} 5^{\prime \prime}$ & $\begin{array}{c}\text { GSP } \\
\text { /Gley-sod-podzolic } \\
\text { soil }\end{array}$ & Birch & $\begin{array}{c}2000 \\
2500 ; 5000\end{array}$ \\
\hline $\begin{array}{c}\text { Dobele/ } \\
\text { Mezansi } \\
\text { (Dob/ } \\
\text { Mez) }\end{array}$ & $56^{\circ} 15.465$ & $25^{\circ} 25.470^{\prime}$ & $\begin{array}{c}\text { /SP } \\
\text { Sod-podzolic soil }\end{array}$ & $\begin{array}{c}\text { Birch } \\
\text { Norway spruce }\end{array}$ & $\begin{array}{l}3300 \\
3300\end{array}$ \\
\hline $\begin{array}{l}\text { Ozolnieki/Medni } \\
\text { (Ozol/ } \\
\text { Med })\end{array}$ & $56^{\circ} 33.005^{\prime}$ & $24^{\circ} 04.212^{\prime}$ & $\begin{array}{c}\text { SPG } \\
\text { Sod } \\
\text { podzolic gley soil }\end{array}$ & $\begin{array}{c}\text { Birch } \\
\text { Scots pine } \\
\text { Norway spruce }\end{array}$ & $\begin{array}{l}3300 \\
1600 \\
5000 \\
2000\end{array}$ \\
\hline $\begin{array}{l}\text { Iecava/ } \\
\text { Skujenieki } \\
\text { (Iec/Skuj) }\end{array}$ & $56^{\circ} 32.605^{\prime}$ & $24^{\circ} 19.414^{\prime}$ & $\begin{array}{c}\text { ASG } \\
\text { Alluvial sod-gley } \\
\text { soil }\end{array}$ & $\begin{array}{c}\text { Birch } \\
\text { Scots pine } \\
\text { Norway spruce }\end{array}$ & $\begin{array}{l}3300 \\
5000 \\
3300\end{array}$ \\
\hline $\begin{array}{c}\text { Iecava/ } \\
\text { Gailịi } \\
\text { (Iec/Gaiḷ) }\end{array}$ & $56^{\circ} 34.192^{\prime}$ & $24^{\circ} 08.863^{\prime}$ & $\begin{array}{c}\text { CS } \\
\text { Strongly altered by } \\
\text { cultivation soil }\end{array}$ & $\begin{array}{c}\text { Birch } \\
\text { Norway spruce }\end{array}$ & $\begin{array}{l}2500 \\
3300 \\
2500\end{array}$ \\
\hline $\begin{array}{c}\text { Viesite/ } \\
\text { Palsani } \\
\text { (Vies/Pals) } \\
\end{array}$ & $56^{\circ} 15^{\prime} 28^{\prime \prime}$ & $25^{\circ} 25^{\prime} 23^{\prime \prime}$ & $\begin{array}{c}\text { BUB } \\
\text { Base-unsaturated } \\
\text { brown soil }\end{array}$ & $\begin{array}{c}\text { Birch/ } \\
\text { Norway spruce }\end{array}$ & $\begin{array}{l}3300 \\
3300\end{array}$ \\
\hline $\begin{array}{l}\text { Rezekne/ } \\
\text { Bitītes } \\
\text { (Rēz/Bit) }\end{array}$ & $56^{\circ} 14.763^{\prime}$ & $27^{\circ} 17.277^{\prime}$ & $\begin{array}{c}\text { SP } \\
\text { Sod-podzolic soil }\end{array}$ & $\begin{array}{c}\text { Birch } \\
\text { Scots pine } \\
\text { Norway spruce }\end{array}$ & $\begin{array}{l}2000 \\
2500 \\
5000 \\
3300\end{array}$ \\
\hline $\begin{array}{l}\text { Madona/ } \\
\text { Birzes } \\
\text { (Mad/Birz) }\end{array}$ & $56^{\circ} 54^{\prime} 55^{\prime \prime}$ & $25^{\circ} 57^{\prime} 16^{\prime \prime}$ & $\begin{array}{c}\text { SP } \\
\text { Sod-podzolic soil }\end{array}$ & $\begin{array}{c}\text { Birch } \\
\text { Scots pine } \\
\text { Norway spruce }\end{array}$ & $\begin{array}{l}2000 \\
2500 \\
5000 \\
3300 \\
\end{array}$ \\
\hline $\begin{array}{l}\text { Amata/ } \\
\text { Laubites } \\
\text { (Amat/ } \\
\text { Laub) } \\
\end{array}$ & $57^{\circ} 0 ’ 15^{\prime \prime}$ & $25^{\circ} 12^{\prime} 16^{\prime \prime}$ & $\begin{array}{c}\text { /SP } \\
\text { Sod-podzolic soil }\end{array}$ & $\begin{array}{c}\text { Birch } \\
\text { Norway Spruce }\end{array}$ & $\begin{array}{l}3300 \\
3300\end{array}$ \\
\hline $\begin{array}{c}\text { Gulbene/ } \\
\text { Sopuli } \\
\text { (Gulb/Sop) }\end{array}$ & $57^{\circ} 09^{\prime} 25$ & $26^{\circ} 58^{\prime} 33^{\prime \prime}$ & $\begin{array}{c}\text { AHG } \\
\text { Alluvial humic- } \\
\text { gley soil }\end{array}$ & Birch & 3300 \\
\hline $\begin{array}{c}\text { Koceni/ Zarini } \\
\text { (Amat/ } \\
\text { Zar) }\end{array}$ & $57^{\circ} 39^{\prime} 17^{\prime \prime}$ & $25^{\circ} 03^{\prime} 22^{\prime \prime}$ & $\begin{array}{c}\text { TSP } \\
\text { Typical sod- } \\
\text { calcareous soil }\end{array}$ & Birch & 3300 \\
\hline
\end{tabular}


WinDendro 2007, by determining the annual treering widths and the number of tree-rings in relevant cut heights.

According to the latest data of the prices of pulpwood (EUR per $\mathrm{m}^{3}$ ) and wood waste (EUR/loose $\mathrm{m}^{3}$ ) calculated the gross income 15-year-old pine, spruce and birch plantations ${ }^{4}$.

Mathematical data processing and credibility calculation was done by mathematical-statistical methods using Microsoft Office Excel 2003 software; mean data, standard deviations and relative error have been calculated using SPSS software (Arhipova \& Balina, 2006).

The significance of variance difference determined using a two-way analysis of variance without replication (Anova: Two-Factor without Replication) (Arhipova \& Balina, 2006).

\section{Results and Discussion}

Six pine (Pinus sylvestris L.), nine spruce (Picea abies (L.) Karst.), thirteen common silver birch (Betula pendula Roth) plantations have been assessed that were established in 1997 on agricultural land using various planting densities -2500 and 3300 , 5000 trees $\mathrm{ha}^{-1}$. During fifteen years, the growth and productivity of these plantations in different soil types have been researched (Table 1).

By assessing the growth of pine plantations in 6 different soil types (TP, SPG, GSC, ASG, SP,) we conclude that in 15-year-old plantations the tree height has reached on average 7.3-7.7 $\mathrm{m}$, except the pines in heavy gley soil (GSC), where their average height is considerably smaller - $6.8 \mathrm{~m}$ (Table 2).

Pine has reached breast height $(1.3 \mathrm{~m})$ in experimental sites only at the age of 6 years, which indicates that its growth was affected by both agrochemical and physically-mechanical indices of the soil, and the abundant above-ground herbaceous vegetation (Daugaviete et al., 2015).

When comparing the growth of pine in 15-yearold plantations in $\mathrm{AL}$ and in forest land, it was concluded that the mean height of pine $\mathrm{H}=7.5 \mathrm{~m}$ is comparable to 17 -year-old pine in dominant height site index $\mathrm{H}_{20}=9 \mathrm{~m}\left(\mathrm{H}_{100}=28 \mathrm{~m}\right)^{5}$.

The largest volumes have been recorded in the trials Grob/Bērz (TP), Iec/Skuj (ASG) and Ozoln/ Med (SPG), where in 15-year-old plantations the volumes have been marked as $152 \mathrm{~m}^{3} \mathrm{ha}^{-1}, 102 \mathrm{~m}^{3} \mathrm{ha}^{-1}$ and $115 \mathrm{~m}^{3} \mathrm{ha}^{-1}$ respectively (Table 2 ). It must be noted that in the trial Grob/Bērz (TP) the plantation survival was $98 \%$ until the age of 15 years, and this plantation shows the largest current volume increment per year - $8.94 \mathrm{~m}^{3} \mathrm{ha}^{-1}$, despite the fact that the volume of mean tree is comparatively smaller than in lower stocking density plantations.

As indicated by the data of Table 2, significantly smallest stem volume of mean tree in 15-year-old plantations, compared to other plantations, has been

Stand data of pine plantations on different soils (age $15 \mathrm{yr}$.)

\begin{tabular}{|c|c|c|c|c|c|c|c|c|}
\hline $\begin{array}{c}\text { Experimental } \\
\text { trial }\end{array}$ & $\begin{array}{c}\text { Soil } \\
\text { type }\end{array}$ & $\begin{array}{c}\text { Density } \\
\text { stems ha }^{-1}\end{array}$ & $\mathrm{D}, \mathrm{cm}$ & $\mathrm{H}, \mathrm{m}$ & $\begin{array}{c}\text { Volume } \\
\text { of mean } \\
\text { tree, } \mathrm{m}^{3}\end{array}$ & $\begin{array}{c}\text { Volume, } \\
\mathrm{m}^{3} \\
\mathrm{ha}^{-1}\end{array}$ & $\begin{array}{c}\text { Average } \\
\text { volume } \\
\text { increment } \\
\mathrm{m}^{3} \mathrm{ha}^{-1} \text { per } \\
\text { year }\end{array}$ & $\begin{array}{c}\text { Significant } \\
\text { difference at } \\
p<0.05\end{array}$ \\
\hline Grob/Bērz & TP & 3774 & $11,6 \pm 2,78$ & $7.7 \pm 0.60$ & 0,0404 & 152 & 8.94 & $\begin{array}{c}\text { Except Iec/ } \\
\text { Skuj } \\
(p>0.05)\end{array}$ \\
\hline Kand/Aizl & GSC & 2651 & $13.9 \pm 2.6$ & $7.3 \pm 0.74$ & 0,0300 & 79 & 4.44 & Between all \\
\hline Ozol/Med & SPG & 2925 & $12.9 \pm 2.6$ & $7.4 \pm 0.95$ & 0,0392 & 115 & 4.06 & Between all \\
\hline Iec/Skuj & ASG & 1853 & $12.7 \pm 2.2$ & $7.7 \pm 0.43$ & 0,0551 & 102 & 5.26 & $\begin{array}{c}\text { Except Ozol/ } \\
\text { Med } \\
(p>0.05)\end{array}$ \\
\hline Rēz/Bit & SP & 1510 & $10,3 \pm 2.88$ & $8,2 \pm 0.90$ & 0,0589 & 89 & 5.77 & $\begin{array}{c}\text { Except Ozol/ } \\
\text { Med } \\
(p>0.05)\end{array}$ \\
\hline
\end{tabular}

4 http://data.csb.gov.lv/pxweb/lv/lauks/lauks_ikgad__mezsaimn/MS080_euro.px/table/tableViewLayout1/?rxid= cdcb978c-22b0-416a-aacc-aa650d3e2ce0; http://www.mezsaimnieks.lv/lv/koksnes_tirgus_apskats/

5 http://www.vmd.gov.lv/valsts-meza-dienests/statiskas-lapas/normativie-akti-?id=807\#jump_MK noteikumi Nr.647 Mežaudzes novērtēšanas kārtība, pieņemti 25.06.2009 
The average indices of sample tree above-ground biomass (freshly-cut/abs. dry/\%) in 15-year old pine plantations

\begin{tabular}{|c|c|c|c|}
\hline Trials & $\begin{array}{c}\text { Total biomass, freshly-cut, } \\
\text { kg/abs. dry,kg/\% }\end{array}$ & $\begin{array}{c}\text { Stem mass } \\
\text { freshly-cut, kg/ } \\
\text { abs. dry,kg/ } \\
\%\end{array}$ & $\begin{array}{c}\text { Branch mass, } \\
\text { freshly-cut,kg/abs. dry } \\
\mathrm{kg} / \%\end{array}$ \\
\hline Grob/Bērz & $174.42 / 106.05 / 100$ & $143.14 / 87.03 / 82.1$ & $31.28 / 19.02 / 17.9$ \\
\hline Ozol/Med & $210.52 / 128 / 100$ & $170.1 / 103.42 / 80.8$ & $40.42 / 24.57 / 19.2$ \\
\hline Iec/Skuj & $185.52 / 112.80 / 100$ & $132.12 / 80.32 / 71.2$ & $53.4 / 32.47 / 28.8$ \\
\hline $\begin{array}{c}\text { Average } \\
\text { freshly-cut, kg } \\
\text { abs. dry,kg } \\
\%\end{array}$ & $190.15 \pm 15.1$ & $148.45 \pm 15.95$ & $41.7 \pm 9.1$ \\
& 115.61 & 90.26 & $25.35 /$ \\
\end{tabular}

marked in the trial site Kand/Aizl, in heavy gley soil (GSC).

In the researched pine plantations, the biggest volumes at the age of 15 years have also been registered in the trials with the largest tree amount per unit area, considering that the volumes of mean tree in individual plantations are smaller.

By performing the sample tree analysis, the research of pine plantation above-ground biomass volume dynamics suggests that the above-ground biomass of mean tree in 15-year-old pine plantations constitutes on average $190.15 \mathrm{~kg}(100 \%)$, including stem biomass $148.5 \mathrm{~kg}(78 \%)$ and crown biomass (branches plus needles) $41.7 \mathrm{~kg}$ (22\%) (Table 3).

If planned to manage this kind of plantation as a roundwood production plantation, it is necessary to do the first thinning of the standing volume. The projected volume of timber and biomass to be felled has been calculated by considering the number of trees to be felled and the standing volume of the

The amount of timber, pulpwood plus wood waste biomass $\left(\mathrm{m}^{3} \mathrm{ha}^{-1} ; \mathrm{t} \mathrm{ha}^{-1}\right)$ and gross income (EUR) obtainable from 15-year-old pine plantations

\begin{tabular}{|c|c|c|c|c|c|c|}
\hline \multirow[b]{2}{*}{ Trial } & \multirow{2}{*}{$\begin{array}{l}\text { Timber volume } \\
\text { obtainable } \\
\text { during } \\
\text { thinning, } \mathrm{m}^{3} \\
\text { ha }^{-1}\end{array}$} & \multirow{2}{*}{$\begin{array}{l}\text { Obtainable } \\
\text { pulpwood/ } \\
\text { fire wood } \\
\text { volume, } \\
\mathrm{m}^{3} \mathrm{ha}^{-1}\end{array}$} & \multirow{2}{*}{$\begin{array}{l}\text { Total obtainable } \\
\text { biomass } \\
\text { (stem wood }+ \\
\text { branches) } \mathrm{t} \text { ha }^{-1} \\
\text { (freshly-cut)/abs. } \\
\text { dry }\end{array}$} & \multicolumn{2}{|c|}{$\begin{array}{l}\text { Gross income from } 1 \text { ha, } \\
\text { EUR }\end{array}$} & \multirow{2}{*}{$\begin{array}{c}\text { Gross } \\
\text { income } \\
\text { from } 1 \text { ha, } \\
\text { (pulpwood/ } \\
\text { fire wood/ } \\
\text { branch } \\
\text { biomass), } \\
\text { EUR }\end{array}$} \\
\hline & & & & $\begin{array}{c}\text { Pulp-wood/ } \\
\text { fire wood } \\
(30 / 20 \text { EUR } \\
\left.\mathrm{m}^{3}\right)\end{array}$ & $\begin{array}{c}\text { Stem waste } \\
\text { and branch } \\
\text { biomass } \\
(7.00 \text { EUR } \\
\left(\text { loose } \mathrm{m}^{3}\right)^{-1}\end{array}$ & \\
\hline Grob/Bērz & 99 & $50 / 49$ & $52 / 11$ & $1500 / 800$ & 367 & 2267 \\
\hline Kand/Aizl & 40 & $20 / 20$ & $11 / 9$ & $600 / 180$ & 297 & 1077 \\
\hline Rēz/Bit & 12 & $6 / 6$ & $6 / 3$ & $180 / 120$ & 100 & 400 \\
\hline Iec/Skuj & 30 & $15 / 15$ & $16 / 4$ & $450 / 300$ & 133 & 883 \\
\hline Ozol/Med & 64 & $32 / 32$ & $17 / 7$ & $960 / 640$ & 233 & 1833 \\
\hline
\end{tabular}

\footnotetext{
6 http://data.csb.gov.lv/pxweb/lv/lauks/lauks_ikgad__mezsaimn/MS080_euro.px/table/tableViewLayout1/ ?rxid=cdcb978c-22b0-416a-aacc-aa650d3e2ce0
} 
pine mean tree stem wood and branch biomass. Calculations show that the highest pulpwood volume and wood biomass in the first thinning is obtainable from plantations that have retained the initial planting density (Table 4).

According to the latest data, the prices of pine pulpwood currently fluctuate between 29-31 EUR per $1 \mathrm{~m}^{3}$ and gross income from pulpwood, after thinning of 15-year-old plantations, has been calculated to be 400-2267 EUR ha-1. The net income from the first thinning of the standing volume of a 15-year-old pine plantation will make around $45 \%$ of gross income for pulpwood and woodchips respectively ${ }^{6}$.

The assessment of the growth of spruce plantations on AL had been done on 9 sites, and their growth and cumulative productivity been researched in plantations on agricultural lands in naturally dry mineral soils (SP, BUB, CS, ASG and PGx) (Table 5).

The data acquired in experiments show that by carrying out timely agrotechnical tending in sodpodzolic agricultural lands the spruce mean height at the age of 15 years had reached $8.2 \mathrm{~m}$, which corresponds to spruce dominant height of site index I $\left(\mathrm{H}_{20}=12 \mathrm{~m}\right)$ in forest stands ${ }^{5}$. Whereas the spruce mean height in soils was strongly altered by cultivation (Iec/ Gail) and in plantations at the age of 15 years, where additional fertilization has been done (Amat/Laub), it reaches $\mathrm{H}=10.5 \mathrm{~m}$, corresponding to 16-18-year-old site index I spruce dominant height in forest stands, in forest soils ${ }^{5}$.

In rich $\mathrm{AL}(\mathrm{CS}, \mathrm{ASG}, \mathrm{SPG})$ the tree mean diameter at breast height in 15-year-old plantations is respectively $8.3-12.6 \mathrm{~cm}$, height $\mathrm{H}=7.1-8.9 \mathrm{~m}$, stem volume of mean tree $25.83-53.43 \mathrm{dm}^{3}$, and standing volume $51-87 \mathrm{~m}^{3} \mathrm{ha}^{-1}$. But the current standing volume increment in these trials constitutes $6.57-15.76 \mathrm{~m}^{3} \mathrm{ha}^{-1}$ per year (Table 5).

When determining the spruce plantation aboveground biomass volume, it was found that in 15-yearold plantation the above-ground biomass of mean tree constitutes on average $142.9 \mathrm{~kg}(100 \%)$ : including stem biomass $65.7 \mathrm{~kg}$ (46\%) and crown biomass (branches plus needles) - $76.9 \mathrm{~kg}(53.9 \%)$, which in

The productivity of spruce plantations in $\mathrm{AL}$ at the age of 15 years

Table 5

\begin{tabular}{|c|c|c|c|c|c|c|c|c|}
\hline Trial & $\begin{array}{l}\text { Soil } \\
\text { type }\end{array}$ & $\mathrm{D}, \mathrm{cm}$ & $\mathrm{H}, \mathrm{m}$ & $\mathrm{V}, \mathrm{dm}^{3}$ & $\begin{array}{l}\text { Volume, } \\
\mathrm{m}^{3} \mathrm{ha}^{-1}\end{array}$ & $\begin{array}{l}\mathrm{N}, \text { trees } \\
\mathrm{ha}^{-1}\end{array}$ & $\begin{array}{c}\mathrm{Z}_{\mathrm{M}}, \\
\mathrm{m}^{3} \mathrm{ha}^{-1} \\
\text { per year }\end{array}$ & $\begin{array}{c}\text { Significant } \\
\text { difference at } 0.05 \\
\text { level }(p<0.05)\end{array}$ \\
\hline Dob/Mež & SP & $9.2 \pm 1.98$ & $7.7 \pm 0.71$ & 31.85 & 75 & 2840 & 7.42 & $\begin{array}{c}\text { Except Vies/Pals, } \\
\text { Mad/Birz }\end{array}$ \\
\hline Iec/Skuj & ASG & $12.6 \pm 2.31$ & $7.7 \pm 0.71$ & 53.43 & 87 & 2660 & 15.76 & Except Vies/Pals \\
\hline Vies/Pals & BUB & $7.9 \pm 2.39$ & $6.7 \pm 0.86$ & 20.49 & 47 & 3128 & 5.51 & $\begin{array}{l}\text { Except Dob/Mež, } \\
\text { Mad/Birz }\end{array}$ \\
\hline $\begin{array}{c}\text { Amat/ } \\
\text { Laub } \\
\text { (after } \\
\text { tending) }\end{array}$ & SP & $12.3 \pm 2.65$ & $10.5 \pm 0.91$ & 66.89 & 98 & 1400 & 14.59 & Between all \\
\hline Mad/Birz & SP & $10.5 \pm 1.48$ & $7.8 \pm 0.69$ & 38.92 & 97 & 3100 & 5.29 & $\begin{array}{c}\text { Except } \\
\text { Dob/Mež, Vies/ } \\
\text { Pals }\end{array}$ \\
\hline Rēz/Bit & SP & $9.4 \pm 2.87$ & $7.4 \pm 1.91$ & 30.45 & 89 & 2957 & 8.66 & Except Vies/Pals \\
\hline $\begin{array}{c}\text { Iec/Gail, } \\
(3300 \\
\text { trees/ha })\end{array}$ & $\mathrm{CS}$ & $10.6 \pm 2.87$ & $8.9 \pm 1.91$ & 39.60 & 85 & 2230 & 10.26 & Except Iec/Skuj \\
\hline $\begin{array}{c}\text { Iec/Gail, } \\
(2500 \\
\text { trees/ha })\end{array}$ & $\mathrm{CS}$ & $10.9 \pm 2.40$ & $9.5 \pm 1.12$ & 49.13 & 75 & 2165 & 13.04 & Except Iec/Skuj \\
\hline $\begin{array}{c}\text { Ozol/ } \\
\text { Med }\end{array}$ & SPG & $8.3 \pm 2.12$ & $7.1 \pm 1.01$ & 25.83 & 51 & 2640 & 6.57 & Between all \\
\hline
\end{tabular}


The average indices of sample tree above-ground biomass (freshly-cut/abs. dry)

Table 6 in 15-year-old spruce plantations

\begin{tabular}{|c|c|c|c|c|c|}
\hline \multirow{3}{*}{ Trial } & \multirow{3}{*}{$\begin{array}{l}\text { Total biomass, } \\
\mathrm{kg} / \%\end{array}$} & \multirow{3}{*}{$\begin{array}{c}\text { Stem } \\
\text { biomass, kg/ } \\
\%\end{array}$} & \multicolumn{3}{|c|}{ Tree crown biomass } \\
\hline & & & \multirow{2}{*}{$\begin{array}{l}\text { Live branches, } \\
\mathrm{kg} / \%\end{array}$} & \multicolumn{2}{|c|}{ Incl., needles } \\
\hline & & & & $\mathrm{kg}$ & $\begin{array}{c}\% \text { of stem } \\
\text { biomass }\end{array}$ \\
\hline Iec/Gail & $176.5 / 100$ & $85.3 / 48.3$ & $91.0 / 51.5$ & 44.1 & 25.0 \\
\hline Iec/Skuj & $142.9 / 100$ & $65.7 / 46.0$ & $76.9 / 53.8$ & 38.1 & 26.7 \\
\hline Mad/Birz & $152.7 / 100$ & $66.5 / 43.5$ & $85.8 / 56.2$ & 46.3 & 30.3 \\
\hline Vies/Pals & $122.1 / 100$ & $50.1 / 41.0$ & $72.0 / 59.0$ & 34.6 & 28.3 \\
\hline Dob/Mež & $134.5 / 100$ & $60.8 / 45.2$ & $73.4 / 54.6$ & 36.6 & 27.2 \\
\hline Ozol/Med & $128.7 / 100$ & $65.9 / 51.2$ & $62.3 / 48.4$ & 28.8 & 22.4 \\
\hline $\begin{array}{c}\text { Average } \\
\text { freshly-cut,kg } \\
\text { /abs. dry,kg } \\
\%\end{array}$ & $\begin{array}{c}142.9 / \\
65.73 / \\
100\end{array}$ & $\begin{array}{c}65.7 / \\
30.22 / \\
46\end{array}$ & $\begin{array}{c}35.37 / \\
54\end{array}$ & 38.1 & 26.7 \\
\hline
\end{tabular}

turn splits into branch biomass - $31.6 \mathrm{~kg}(41 \%)$, and needle biomass $-45.30 \mathrm{~kg}(59 \%)$ (Table 6).

To calculate the potential gross income from spruce plantations after the thinning - first thinning - sample trees have been taken out and analyzed in most characteristic plantation trials: Mad/Birz, Vies/ Pals, Dob/Mež, Iec/Gail and Iec/Skuj, where thinning had not been done before. Based on sample tree data, the volume of obtainable products - pulpwood, branch biomass and raw biomass (needle and non-ligneous shoots) - has been calculated. According to the latest data, the prices ${ }^{5}$ of spruce pulpwood currently fluctuate between 29-30 EUR per $1 \mathrm{~m}^{3}$ and gross income from pulpwood, after thinning of 15-year-old

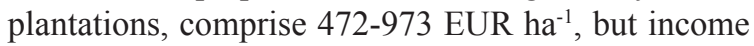
from branch biomass - 312-1015 EUR ha-1.

The net income from the first thinning of the standing volume of a 15-year-old spruce plantation will make around $40 \%$ of gross income 6 . Thus, it was concluded that the net income from the total stem

Table 7

The potential timber volume to be felled during thinning of 15 -year-old spruce plantations, the volume of obtainable green crown biomass and gross income $\left(\mathrm{m}^{3} \mathbf{h a}^{-1}, \mathrm{t} \mathrm{ha}^{-1}, \mathbf{E U R} \mathbf{h a}^{-1}\right)$

\begin{tabular}{|c|c|c|c|c|c|c|c|c|}
\hline \multirow{2}{*}{$\begin{array}{c}\text { Spruce } \\
\text { plantations }\end{array}$} & \multirow[b]{2}{*}{$\begin{array}{l}\text { Timber } \\
\text { volume } \\
\text { obtainable } \\
\text { during } \\
\text { thinning, } \\
\mathrm{m}^{3} \mathrm{ha}^{-1}\end{array}$} & \multirow{2}{*}{$\begin{array}{c}\text { Obtainable } \\
\text { pulpwood/ } \\
\text { fire wood } \\
\text { volume, } \mathrm{m}^{3} \\
\text { ha }^{-1}\end{array}$} & \multirow[b]{2}{*}{$\begin{array}{c}\text { Total } \\
\text { obtainable } \\
\text { biomass } \\
\text { (stem } \\
\text { wood + } \\
\text { branches), } \\
\text { t ha }^{-1} \\
\text { (freshly- } \\
\text { cut/abs. } \\
\text { dry) }\end{array}$} & \multirow[b]{2}{*}{$\begin{array}{l}\text { Including } \\
\text { raw } \\
\text { biomass } \\
\text { (needles } \\
\text { plus new } \\
\text { shoots), } \mathrm{t} \\
\text { ha }^{-1}\end{array}$} & \multicolumn{3}{|c|}{ Gross income from 1 ha, EUR } & \multirow[b]{2}{*}{$\begin{array}{c}\text { Gross } \\
\text { income } \\
\text { (pulpwood/ } \\
\text { fire wood/ } \\
\text { felling waste } \\
\text { and branch } \\
\text { biomass), } \\
\text { EUR ha-1 }^{-1}\end{array}$} \\
\hline & & & & & $\begin{array}{c}\text { Pulpwood/ } \\
\text { fire wood } \\
(29.5 / 20 \\
\text { EUR per } \\
\left.\mathrm{m}^{3}\right), \text { EUR }\end{array}$ & 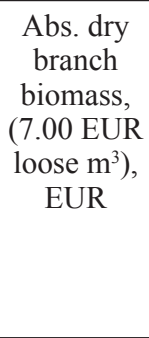 & $\begin{array}{c}\text { Raw } \\
\text { needle } \\
\text { and new } \\
\text { shoot } \\
\text { biomass } \\
(130 \\
\left.\text { EUR t }{ }^{-1}\right), \\
\text { EUR }\end{array}$ & \\
\hline Mad/Birz & 54 & $27 / 27$ & $66 / 39$ & 8 & $737 / 480$ & 1015 & 1040 & 3272 \\
\hline Iec/Gail & 33 & $16 / 17$ & $40 / 23$ & 4 & $472 / 340$ & 312 & 520 & 1644 \\
\hline Vies/Pals & 36,5 & $18 / 18$ & $45 / 26$ & 4.6 & $531 / 360$ & 342 & 598 & 1831 \\
\hline Iec/Skuj & 67 & $33 / 34$ & $82 / 48$ & 7.8 & $973 / 680$ & 507 & 1014 & 3174 \\
\hline Dob/Mež & 46 & $23 / 23$ & $56 / 33$ & 5.3 & $678 / 460$ & 436 & 689 & 2263 \\
\hline
\end{tabular}


volume to be felled in 15-year-old spruce plantations, including the raw needle mass, is on average 1.5 times greater when compared to the scenario where only pulpwood and branch biomass is sold (Table 7).

The research on the growth of birch and productivity on former AL, in naturally dry mineral soils, it is suggested that overall, compared to conifers, the growth of birch in these plantations is more dynamic (Daugaviete et. al. 2015, Daugaviete and Liepinšs 2014).

The greatest birch height recorded exactly in plantations in fertile agricultural soils - in soil

Table 8

Birch plantation characterizing parameters in various agricultural land soils at the age of 15 years

\begin{tabular}{|c|c|c|c|c|c|c|c|c|}
\hline Trial & $\begin{array}{l}\text { Soil } \\
\text { type }\end{array}$ & $\mathrm{D}, \mathrm{cm}$ & $\mathrm{H}, \mathrm{m}$ & $\mathrm{V}, \mathrm{dm}^{3}$ & $\begin{array}{l}\mathrm{M}, \mathrm{m}^{3} \\
\mathrm{ha}^{-1}\end{array}$ & $\begin{array}{l}\mathrm{N} \text {, trees } \\
\mathrm{ha}^{-1}\end{array}$ & $\begin{array}{l}\mathrm{Z}_{\mathrm{M}}, \\
\mathrm{m}^{3} \mathrm{ha}^{-1} \\
\text { per year }\end{array}$ & $\begin{array}{l}\text { Significant } \\
\text { difference } \\
\text { at } 0.05 \text { level } \\
(p<0.05)\end{array}$ \\
\hline Grob/Bērz & $\mathrm{TP}$ & $10.6 \pm 2.71$ & $12.3 \pm 1.14$ & 53.43 & 82 & 1758 & 14.33 & $\begin{array}{c}\text { Except Iec/ } \\
\text { Skuj, Vies/Pals }\end{array}$ \\
\hline Kuld/Rūm & GSP & $11.6 \pm 1.71$ & $12.8 \pm 0.80$ & 65,94 & 101 & 1952 & 12.17 & $\begin{array}{l}\text { Except Grob/ } \\
\text { Bērz, } \\
\text { Ozol/Med, Iec/ } \\
\text { Skuj }\end{array}$ \\
\hline Kand/Aiz!̣ & GSC & $7.9 \pm 2.21$ & $8.5 \pm 1.00$ & 21,93 & 36 & 2165 & 4.66 & Between all \\
\hline Dob/Mež & SP & $10.5 \pm 2.60$ & $14.2 \pm 1.82$ & 59,59 & 128 & 2650 & 13.49 & $\begin{array}{l}\text { Except Ozol/ } \\
\text { Med, } \\
\text { Kuld/Rūm, } \\
\text { Rēz/Bit }\end{array}$ \\
\hline Iec/Skuj & ASG & $10.3 \pm 2.80$ & $12.5 \pm 2.3$ & 51,26 & 138 & 2500 & 21.69 & $\begin{array}{c}\text { Except Kand/ } \\
\text { Aizl, Kuld/ } \\
\text { Rūmn, Vies/ } \\
\text { Pals, }\end{array}$ \\
\hline Vies/Pals & BUB & $10.9 \pm 1.96$ & $14.3 \pm 1.06$ & 64,49 & 145 & 2928 & 25.11 & $\begin{array}{l}\text { Except Kand/ } \\
\text { Aizl, Iec/Skuj }\end{array}$ \\
\hline Amat/Laub & $\mathrm{SP}$ & $9.7 \pm 2.60$ & $13.3 \pm 1.83$ & 50,46 & 112 & 2214 & 15.72 & $\begin{array}{l}\text { Except Kand/ } \\
\text { Aizl, Rēz/Bit, } \\
\text { Ozol/Med }\end{array}$ \\
\hline Koc/Zar & TSP & $10.4 \pm 2.35$ & $12.8 \pm 1.55$ & 53,34 & 131 & 2354 & 20.97 & $\begin{array}{c}\text { Except Grob/ } \\
\text { Bērz, Iec/Skuj, } \\
\text { Vies/Pals }\end{array}$ \\
\hline $\begin{array}{c}\text { Mad/Birz } \\
\text { (2500 trees/ha }\end{array}$ & SP & $10.8 \pm 3.3$ & $13.0 \pm 2.18$ & 58,20 & 135 & 1650 & 12.07 & $\begin{array}{c}\text { Except Grob/ } \\
\text { Bērz, Ozol/ } \\
\text { Med, Iec/Skuj }\end{array}$ \\
\hline Gulb/Sop & $\mathrm{ASH}$ & $12.5 \pm 2.49$ & $12.1 \pm 0.55$ & 72.47 & 60 & 861 & 8.30 & Between all \\
\hline Rēz/Bit & SP & $8.8 \pm 3,6$ & $10.0 \pm 3,0$ & 43.91 & 61 & 1400 & 3.72 & $\begin{array}{c}\text { Except Grob/ } \\
\text { Bērz, Ozol/ } \\
\text { Med, Iec/Skuj }\end{array}$ \\
\hline Iec/Gail & $\mathrm{CS}$ & $13.9 \pm 2.46$ & $16.2 \pm 1.06$ & 90.92 & 169 & 1675 & 29.82 & Between all \\
\hline $\begin{array}{c}\text { Ozol/Med } \\
\text { (initially } 3000 \\
\text { trees per ha) }\end{array}$ & SPG & $12.6 \pm 2.06$ & $14.0 \pm 1.53$ & 48.86 & 143 & 2765 & 29.72 & Except Iec/Gail \\
\hline $\begin{array}{l}\text { Ozol/Med } \\
\text { (initially } 1600 \\
\text { trees/ha) }\end{array}$ & SPG & $13.2 \pm 2.29$ & $14.7 \pm 1.04$ & 98.53 & 122 & 1480 & 24.97 & Except Iec/Gail \\
\hline
\end{tabular}


strongly altered by cultivation in the trial Iec/Gail, and in podzolic pseudogley soil in the trial Ozol/ Med; the mentioned soils had been extendedly used in agricultural production (Table 8), here the mean height of birch at the age of 15 years marked as $15.3 \mathrm{~m}$.

In the plantations in sod-podzolic soils, the mean height of birch varies from $11.7 \mathrm{~m}$ to $14.2 \mathrm{~m}$, in alluvial soils (Iec/Skuj) from $12.2 \mathrm{~m}$ to $12.5 \mathrm{~m}$, in brown soil (Vies/Pals) - $13.6 \mathrm{~m}$, and in gley-sod calcareous soil (Kand/Aizl), on heavy gley base material $-8.5 \mathrm{~m}$ (Table 8).

In the plantations in sod-podzolic soils (Ozol/ Med, Rez/Bit, Mad/Birz), the mean diameter at breast height of birch fluctuates from $9.5 \mathrm{~cm}$ to $10.8 \mathrm{~cm}$, in alluvial soils (Iec/Skuj, Gulb/Sop) - from $10.5 \mathrm{~cm}$ to $12.7 \mathrm{~cm}$, in brown soil (Vies/Pals) - $10.9 \mathrm{~cm}$, and in gley-sod calcareous soil (Kand/Aizl), on heavy gley $7.9 \mathrm{~cm}$ (Table 8).

The productivity of birch plantations at the age of 15 years in different soils vary from 62 to $169 \mathrm{~m}^{3} \mathrm{ha}^{-1}$ (Table 8).

The current standing volume increment in birch plantation experimental trials varies from 7.54 to $29.82 \mathrm{~m}^{3} \mathrm{ha}^{-1}$ per year: the smallest increment -4.66 $\mathrm{m}^{3} \mathrm{ha}^{-1}$ per year - in 15-year-old plantations has been registered in heavy gley soil (Kand/Aizl), but the largest -29.72-29.82 $\mathrm{m}^{3}$ ha per year - in soil strongly altered by cultivation (Iec/Gail), and in pseudogley soil (Ozol/Med) (Table 8).

The data statistical analysis indicates that the productivity of birch plantations at young stand age is significantly smaller $(p \leq 0.05)$ also in heavy gley soils (Kand/Aizl)).

The largest cumulative volumes of mean tree for birch are in pseudogley extendedly cultivated soil (Ozol/Med)-96.04 $\mathrm{dm}^{3}$ and in soil strongly altered by cultivation (Iec/Gal $)-90.92 \mathrm{dm}^{3}$, in alluvial sod-gley soil (Iec/Skuj)-79.83 dm³ (Table 8).
The smallest cumulative volumes of mean tree have been recorded in heavy gley soil in the trial Kand/Aizl-21.93 dm3 (Table 8).

Research on the volume of the birch plantation above-ground biomass indicate that the biomass of a 10-year-old birch constitutes on average $64.93 \pm 12.81 \mathrm{~kg}(100 \%)$, of which the stem takes up $47.95 \pm 9.49 \mathrm{~kg}$ or $74 \%$ of the total tree biomass, but the crown biomass (branches plus leaves) $-16.97 \pm 4.35$ $\mathrm{kg}$ or $26 \%$ of the total tree biomass. A 15 -year-old birch biomass constitutes on average $158.41 \pm 31.72$ $\mathrm{kg}(100 \%)$, including the stem biomass $-121.1 \pm 22.8$ $\mathrm{kg}$ or $76 \%$ of the total tree biomass, but the crown biomass (branches and leaves) $-37.31 \pm 14.35 \mathrm{~kg}$ or $24 \%$ of the total tree biomass (Table 9).

In the research trials the first round tending or thinning is needed to ensure the further growth, by reducing the number of trees and thus obtaining the pulpwood to be sold (Table 10). Its volume calculation has been done by the methodology of modelling roundwood assortment yield in thinning birch plantations (Prindulis et.al., 2013). These investigations show the number of trees after first thinning must be no more than 1100 trees per ha (Zālītis, Dreimanis \& Daugaviete, 2003; P. Zālītis, 2006; T. Zālīitis, 2008; Daugaviete, K.Liepin̄̌s \& J.Liepiñš, 2011; Prindulis et al., 2013; Daugaviete et al., 2015).

According to the latest data, the prices of birch pulpwood ${ }^{4}$ currently fluctuate between 29-30 EUR per $1 \mathrm{~m}^{3}$ and gross income from pulpwood ${ }^{5}$, after first thinning of the standing volume of 15-year-old plantations, constitute 221-1003 EUR ha ${ }^{-1}$, but income from stem and branch residues biomass - 1365$4123 \mathrm{EUR} \mathrm{ha}^{-1}$. Therefore, the net income from the first thinning of the standing volume of a 15 -year-old birch plantation will make around $30-10 \%$ of gross income for pulpwood and woodchips respectively (Table 10).

The average indices of sample tree above-ground biomass (freshly-cut)

Table 9 in 10 to 15-year-old birch plantations

\begin{tabular}{|c|c|c|c|}
\hline Sample tree age, years & $\begin{array}{c}\text { Total biomass } \\
\mathrm{kg} / \%\end{array}$ & $\begin{array}{c}\text { Stem mass } \\
\mathrm{kg} / \%\end{array}$ & $\begin{array}{c}\text { Branch mass, } \\
\mathrm{kg} / \%\end{array}$ \\
\hline 10 y.o. & $64.93 \pm 12.81 /$ & $47.95 \pm 9,49 /$ & $16.97 \pm 4.35 /$ \\
& 100 & 74 & 26 \\
\hline 12 y.o. & $98.23 \pm 7.25 /$ & $70.83 \pm 3.92 /$ & $27.40 \pm 3.45 /$ \\
& 100 & $121.1 \pm 22.88 /$ & $37.31 \pm 14.35 /$ \\
\hline
\end{tabular}


The potential timber volume to be felled during thinning of 15-year-old birch plantations, the volume of obtainable green crown biomass and gross income

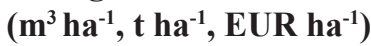

\begin{tabular}{|c|c|c|c|c|c|c|}
\hline \multirow{2}{*}{ Trial } & \multirow{2}{*}{$\begin{array}{l}\text { Timber } \\
\text { volume } \\
\text { obtainable } \\
\text { during } \\
\text { thinning, } \\
\mathrm{m}^{3} \mathrm{ha}^{-1}\end{array}$} & \multirow{2}{*}{$\begin{array}{l}\text { Obtainable } \\
\text { pulpwood/ } \\
\text { firewood } \\
\text { production, } \\
\mathrm{m}^{3} \mathrm{ha}^{-1}\end{array}$} & \multirow{2}{*}{$\begin{array}{c}\text { Total } \\
\text { obtainable } \\
\text { biomass/ } \\
\text { t ha-1 } \\
\text { (freshly-cut/ } \\
\text { abs. dry) }\end{array}$} & \multicolumn{2}{|c|}{ Gross income from 1 ha, EUR } & \multirow{2}{*}{$\begin{array}{c}\text { Gross income } \\
\text { from } 1 \text { ha, } \\
\text { EUR }\end{array}$} \\
\hline & & & & $\begin{array}{c}\text { Pulp-wood / } \\
\text { fire wood }(29.5 \\
/ 20.0 \text { EUR per } \\
\left.\mathrm{m}^{3}\right)\end{array}$ & $\begin{array}{c}\text { branch } \\
\text { biomass }(7.00 \\
\text { EUR per } \\
\text { loose } \mathrm{m}^{3}\end{array}$ & \\
\hline $\begin{array}{l}\text { Grob/ } \\
\text { Bērz }\end{array}$ & 36 & $18 / 18$ & $104 / 65$ & $531 / 360$ & 175 & 1066 \\
\hline $\begin{array}{l}\text { Kuld/ } \\
\text { Rūmn }\end{array}$ & 57 & $28.5 / 28.5$ & $64 / 47$ & $841 / 570$ & 240 & 1651 \\
\hline $\begin{array}{l}\text { Kand/ } \\
\text { Aizl }\end{array}$ & 25 & $7.5 / 17.5$ & $22 / 18$ & $221 / 350$ & 112 & 683 \\
\hline Dob/Mež & 63 & $19 / 44$ & $69 / 52$ & $560 / 880$ & 264 & 1704 \\
\hline Iec/Skuj & 77 & $23 / 54$ & $84 / 74$ & $678 / 1080$ & 324 & 2082 \\
\hline Vies/Pals & 58 & $29 / 29$ & $63 / 48$ & $855 / 580$ & 243 & 1678 \\
\hline $\begin{array}{l}\text { Amat/ } \\
\text { Laub }\end{array}$ & 56 & $17 / 39$ & $49 / 37$ & $501 / 780$ & 91 & 1372 \\
\hline Koc/Zar & 70 & $21 / 49$ & $61 / 47$ & $619 / 980$ & 294 & 1883 \\
\hline $\begin{array}{l}\text { Mad/ } \\
\text { Birzes }\end{array}$ & 33 & $10 / 21$ & $29 / 22$ & $295 / 420$ & 112 & 827 \\
\hline Iec/Gail & 68 & $34 / 34$ & $74 / 56$ & $1003 / 680$ & 285 & 1968 \\
\hline Ozol/Med & 81 & $24 / 57$ & $88 / 67$ & $708 / 1140$ & 340 & 2188 \\
\hline
\end{tabular}

Therefore, the net income from the first thinning of the standing volume of a 15-year-old birch plantation will make around $40 \%$ of gross income and are forecast to be in the amount of 273-875 EUR $\mathrm{ha}^{-1}$.

Our research indicates that for acquisition of energy wood higher stocking density (10000 and 5000 trees per ha) birch plantations can be established, the rotation period of which could be 15 years (Daugaviete et al., 2011). It must be noted that despite the decreasing the number of trees by $26-34 \%$, the total biomass (number of trees $\mathrm{x}$ medium tree mass, $\mathrm{kg}$ ), reaches about 530-942 $\mathrm{t} \mathrm{ha}^{-1}$ (Table 8, Table 9).

Similar conclusions have also been published in Finland and Sweden (Niemisto, 1995; Hynhynen \& Niemisto, 2009), where it has been noted that dense birch plantations must be managed for obtaining energy wood, but sparse plantations must be designated for acquisition of assortment.

\section{Conclusions}

1. The establishment of pine, spruce and birch plantation type forests on former agricultural land secures the acquisition of the first production and net income within 15 years.

2. In $\mathrm{AL}$ (ASG, PGx, SPG, TP) the standing volume of 15-year-old pine plantations reaches 102-155 $\mathrm{m}^{3} \mathrm{ha}^{-1}$ and the current standing volume increment reaches 5.72-8.94 $\mathrm{m}^{3} \mathrm{ha}^{-1}$ per year, under the condition that the plantation survival rate is within $80-95 \%$.

3. The above-ground biomass of 1 tree in 15-year-old pine plantations constitutes on average $190.15 \mathrm{~kg}(100 \%)$, including stem biomass $148.5 \mathrm{~kg}(78 \%)$ and crown biomass (branches plus needles) $41.7 \mathrm{~kg}(22 \%)$.

4. In rich $\mathrm{AL}$ (ASG, CS, SPG) the standing volume of 15-year-old spruce plantations reaches $75-98 \mathrm{~m}^{3} \mathrm{ha}^{-1}$ and the current standing volume increment reaches $10.26-15.76 \mathrm{~m}^{3} \mathrm{ha}^{-1}$ per year, under the condition that the plantation survival rate is within $80-98 \%$.

5. In 15-year-old spruce plantation the aboveground biomass of 1 tree constitutes on average $142.9 \mathrm{~kg}(100 \%)$ : including stem biomass 65.7 $\mathrm{kg}(46.0 \%)$ and crown biomass (branches plus 
needles) - $76.9 \mathrm{~kg}(53.9 \%)$, which in turn splits into branch biomass - $31.6 \mathrm{~kg}$ (41\%), and needle biomass $-45.30 \mathrm{~kg}(59 \%)$.

6. 15-year-old birch plantation standing volume depends on soil fertility and varies from 61 to169 $\mathrm{m}^{3} \mathrm{ha}^{-1}$. The current standing volume increment in birch plantations varies from 7.54 to $29.82 \mathrm{~m}^{3} \mathrm{ha}^{-1}$ per year.

7. 15-year-old birch average biomass comprises $158.41 \pm 31.72 \mathrm{~kg}$, of which the stem mass is $121.1 \pm 22.88 \mathrm{~kg}$ or $76 \%$, but the crown biomass (the mass of branches and leaves) - $37.31 \pm 14.35 \mathrm{~kg}$ or $24 \%$ of the total tree biomass.

8. The first thinning of the standing volume in pine, spruce and birch plantations must be done not later than at the age of 15 years if the plantation survival rate varies within 80 95\%. Gross income from the first thinning of the standing volume in pine plantations varies from 400 to $2267 \mathrm{EUR} \mathrm{ha}^{-1}$, under the condition that pulpwood and felling waste biomass is prepared, in spruce plantations -1644-3272 EUR ha ${ }^{-1}$ if the spruce needles biomass is utilized, in birch plantations -6832188 EUR ha $^{-1}$.

\section{References}

1. Arhipova, I., Balina, S. (2006). Statistika ekonomikā un biznesā (Statistics in economics and business. Solutions with SPSS and Microsoft Excel). Rīga: Datorzinību Centrs, 364.lpp. (in Latvian).

2. Brown, C. (2000). The global outlook for future wood supply from forest plantations. FAO Working Paper No: GFPOS/WP/03, 156 pp.

3. Carnus, J.M., Parrotta, J. and Brockerhoff, E. (2006). Planted forests and biodiversity. J. Forest, 104: 65-77.

4. Daugaviete, M. (2005). Stādījumu biezības ietekme uz bērza (Betula pendula Roth.) augšanas gaitu un masas pieaugumu lauksaimniecības zemju apmežojumos. (The growth of birch (Betula pendula Roth) plantations on the abandoned agricultural lands). Mežzinātne 15(48)2005: 14.-25.lpp. (in Latvian).

5. Daugaviete, M., Lazdina, D., Bambe, B., Bardule, A., Bardulis, A., Daugavietis, U. (2015). Productivity of different tree species in plantations and agricultural soils and related environmental impacts. Baltic Forestry 21(2): 349-358.

6. Daugaviete, M.,Krumina, M., Kaposts, V., Lazdins, A. (2003). Farmland Afforestation: the Performance of Birch Betula pendula Roth. in
Different Soils. Baltic Forestry, Vol. 9, No 1, pp.9-21.

7. Daugaviete, M., Liepiņš, K., Liepiņš, J. (2011). Kārpainā bērza (Betula pendula Roth.) dažādas biezības plantāciju augšanas gaita (The growth of silver birch (Betula pendula Roth.) in plantations of different density). Mežzinātne 24, 3.-16.lpp. (in Latvian).

8. Daugaviete, M. \& Liepiņš, K. (2014). Kādas augsnes bērzam patīk labāk. (Most suitable soils for growing of birch plantations) Broshure "Plantāciju mežu stādī̌sana un kopšana " (Growing and management of plantation forests). Žurn. „AGROTOPS”, bibliotēka: 18.-23.lpp. (In Latvian).

9. Del Lungo, A., Ball, J., Carll, J. (2006). Global planted forests thematic study. Results and analysis. Working. Paper. FAO Paper Rome, Italy: $178 \mathrm{pp}$.

10. Freedman, B. (2005). Benefits of afforestation. In: Proceedings of the AFFORNORD conference „Effects of afforestation on ecosystems, landscape and rural development", June 18-22, Reykholt, Iceland: 13-23.

11. Global Forest Resources Assessment (2015). Food and Agriculture Organization of the United Nations. Rome, 2015, 253 p., Retrieved October 30,2016 from http:/www.fao.org/ publications/card/en/c/f262f48b-fe70-46c89cf3-fd18119c9c3e/.

12. Halldorsson, G., Oddsdottir, ES. Eggertsson, O. (2007). Effects of Afforestation on Ecosystems, Landscape and Rural Development. Proceedings of the AFFORNORD conference, Reykholt, Iceland, June 18-22, 2005, TemaNord 2007:508, 343 pp.

13. Hynynen, J., Niemisto, P., Vihera-Aarnio, A., Brunner, A., Hein, S., Velling, P. (2010). Silviculture of birch ( Betula pendula Roth and Betula pubescens Ehrh.) in northern Europe. Forestry, Vol. 83, No. 1: 103-119.

14. Hynynen, J. and Niemistö, P. (2009) Silviculture of Silver Birch in Finland. (WWW document) http://www.waldwissen.net/lernen/ weltforstwirtschaft/fva_birke_waldbau_ finnland/index_EN.

15. Johansson, T. (1996) Site index curves for Norway Spruce (Picea abies (L.) karst.) planted on abandoned farm land. New Forests, 11: p. 9-29.

16. Kund, M., Vares, A., Sims, A., Tullus, H., Uri, V. (2010). Early growth and development of silver birch (Betula pendula Roth.) plantations on abandoned agricultural land. European Journal of Forest Research, 129(4), 679 - 688. 
17. Lazdinšs, A. (2011). Dabiski apmežojušos lauksaimniecības zemju efektīvas apsaimniekošanas nosacījumi. Promocijas draba kopsavilkums Dr. silv. zin. grāda iegūšanai Mežzinātnes nozarē Meža ekologijas un mežkopības apakšnozarē (Predictions for efficient management of naturally afforested farmlands). LVMI Silava. 51.lpp. (in Latvian).

18. Lazdins, A., Lazdina, D., Daugaviete, M., Makovskis, K. (2011). Dabiski apmežojušos platību apsaimniekošana (Management of naturally afforested agricultural areas). LVMI Silava, 35.lpp. (in Latvian).

19. Liepiņš, K. (2011). Kārpainā bērza (Betula pendula Roth) jaunaudžu augšanas gaita stādījumos lauksaimniecības augsnēs Latvijā (Growth of silver birch Betula pendula Roth.) in plantations on farmlands in Latvia). Mežzinātne 23(56): 3.-14.lpp. (in Latvian).

20. Liepa, I. (1996). Pieauguma mācība (Increment Science). Jelgava, LLU, 123. - 297.lpp. (in Latvian).

21. Maike, P. (1952). Bērzu kultūras augšanas gaita tīruma augsnēs (Growth of siver birch silvicultures on agricultural lands). Mežsaimniecības problēmu institūta raksti, $\mathrm{Nr}$. 4, 43.-57.lpp. (in Latvian).

22. Mather, A. (ed.) (1993). Afforestation: Policies, Planning and Progress. London: Belhaven Press. 223 pp.

23. Nabuurs, G.-J., Schelhaas, M.-J., Orazio, C., Hengeveld, G., Tome, M., Farrell, E. (2014). European perspective on the development of planted forests, including projections to 2065. N.Z. j. of For. Sci. 44, 1-7.

24. Niemisto, P. (1995). Influence of initial spacing and row-to-row distance on the crown and branch properties and taper of silver birch (Betula pendula). Sc.J Forest Research. Volume 10, Issue 1-4: 235-255.

25. Paquette, A., Messier, C. (2010). The role of plantations in managing the world's forests in the Anthropocene. Front Ecol Environ 2010; 8(1): 27-34.

26. Prindulis, U., Donis, J., Šnepsts, G., Strazdiņa, L., Liepiņš, J., Liepiņš, K. (2013). Apalıkoksnes sortimentu iznākuma modelēšana krājas kopšanas cirtēs bērza stādījumos (Modelling roundwood assortment yield in thinning birch plantations). Mežzinātne 27(60): 3.-16.lpp. (in Latvian).

27. Rytter, L., Werner, M. (2007). Influence of early thinning in broadleaved stands on development of remaining stems. Scand. J. For. Res., 22: 198-210.

28. Sacenieks, R., Gaross, V. (1961). Tīrumu augsnēs augošo egḷu audžu ekonomiski izdevīgākais apsaimniekošanas veids (The most profitable management method for Norway spruce stands growing on agricultural lands) LZA Mežsaimniecības problēmu un koksnes k̦īmijas institūts, 54.lpp. (in Latvian).

29. Sarma, P. (1949) Pētījumi par priežu un egḷu audžu augšanas gaitu tīrumu augsnēs (Investigations about growth of Scots pine and Norway spruce stands on agricultural lands). Latvijas PSR Zinātņu Akadēmijas Vēstis, Nr. 7 (24), 31.-42.lpp. (in Latvian).

30. Savill, P., Evans, J. Auclar, D., Falck, J. (1997). Plantation Silviculture in Europe: Oxford University Press. 2002: p 283.

31. Sedjo, R., Botkin, D. (1997). Using forest plantations to spare natural forests. Environment 39(10): 14-20.

32. Tullus, A., Rytter, L., Tullus, T., Weih, M., Tullus, H. (2012). Short-rotation forestry with hybrid aspen (Populus tremula L. X P. tremuloides Michx.) in Northern Europe. Scandinavian Journal of Forest Research, 27(1), 10-29.

33. Zālītis, P. (2006). Mežkopības priekšnosacījumi (Prerequisites of forestry).Rīga: Et cetera: 219. lpp. (in Latvian).

34. Zālītis, P., Dreimanis, A., Daugaviete, M. (2003). Bērza audžu kopšana (Management of siver birch stands). Rīga, A/S Latvijas Finieris, 2003: 51.1pp. (in Latvian).

35. Zālītis, T. (2008). Kārpainā bērza (Betula pendula Roth.) augšanas gaitu un stumbra kvalitāti ietekmējošie faktori auglīgajos meža tipos Latvijā. Promocijas darba kopsavilkums. (The factors influencing the growth and stem quality of Silver birch stands on fertile site types in Latvia). Jelgava: 52. 1pp. (in Latvian).

36. Zanchi G., Thiel D., Green T., Lindner, M. (2007). Afforestation in Europe. Final Version 26/01/07. MEACAP WP4, 41 p.

37. Weber, N. (ed.) (2000). NEWFOR-New Forets for Europe: Afforestation at the Turn of the Century. Proceedings of the Scientific Symposium. No. 35. February 16th-17th, 2000. Freiburg, Germany, 244 p.

38. West, P. W. (2014). Growing Forest Plantations: Springer, $329 \mathrm{pp}$. 